\title{
INFLUENCE OF SELENIUM ON THE MORPHOLOGY OF IMMUNE SYSTEM ORGANS IN HEALTHY BROILERS
}

\author{
KORZENIOWSKA Malgorzata ${ }^{1}$, MADEJ Jan P. ${ }^{2 *}$, \\ STEFANIAK Tadeusz ${ }^{3}$, KOPEC Wieslaw ${ }^{1}$
}

\begin{abstract}
${ }^{1}$ Department of Animal Products Technology and Quality Management, Wroclaw University of Environmental and Life Sciences, Wroclaw, Poland; ${ }^{2}$ Division of Histology and Embryology, Department of Animal Physiology and Biostructure, Wroclaw University of Environmental and Life Sciences, Wroclaw, Poland; ${ }^{3}$ Department of Immunology, Pathophysiology and Veterinary Preventive Medicine, Wroclaw University of Environmental and Life Sciences, Wroclaw, Poland
\end{abstract}

(Received 20 November, Accepted 02 December 2019)

This study aimed to establish the effect of dietary supplementation in broiler chickens of organic and inorganic selenium on the weight and structure of the thymus, bursa of Fabricius and spleen. Three dietary regimes were studied in Flex and F15 Hubbard chickens: (i) control, (ii) diets containing $0.5 \mathrm{mg}$ organic selenium $/ \mathrm{kg}$ by selenized yeast, (iii) diets supplemented with $0.5 \mathrm{mg}$ ionic selenium $/ \mathrm{kg}$ (sodium selenite). The results showed that the feed additives did not affect the relative weight of the immune system organs, i.e. bursa of Fabricius, thymus and spleen. The organic selenium in the F15 resulted in thinning of the thymic cortex and partial depletion of the lymphoid cells. Moreover, both the organic and inorganic selenium supplementation resulted in depopulation of bursal medulla from lymphocytes in the F15 group. In contrast, in Flex chickens no significant differences in histological structure and morphometric values of lymphoid organs between chickens fed organic and inorganic selenium were found.

Key words: selenium, thymus, bursa of Fabricius, spleen, immunology, chicken

\section{INTRODUCTION}

Selenium (Se) is an essential ingredient in chicken diets, regulating key metabolic processes affecting animal health during growth, development and reproduction [1]. Recommended Se levels in bird diets range from 0.15 to $0.30 \mathrm{mg} / \mathrm{kg}$ [2]; at this concentration Se does not affect animal performance [2-4]. However, high levels of inorganic selenium $(10-30 \mathrm{mg} / \mathrm{kg}$ ) result in pathological changes in the liver and kidneys [5].

Selenium can significantly improve bird antibody immune responses in natural and pathological conditions [3,6-8], although an overly elevated amount of this micronutrient

\footnotetext{
*Corresponding author: e-mail: jan_madej@interia.pl
} 
in the diet (3-60 mg/ kg) can decrease body weight and reduce the immune response [6,9]. Moreover, selenium incorporated into iodothyronine deiodinases may influence the thyroid function and via the thyroid other immunological organs [10].

The purpose of this study was to examine the effects of selenium supplementation in broiler chickens on the weight and structure of the thymus, bursa of Fabricius (BF) and spleen. Research hypothesis: high levels of selenium supplementation have effects on broilers weight and structure of the thymus, BF and spleen.

\section{MATERIAL AND METHODS}

\section{Experiment design}

All procedures carried out on the animals were approved by the Local Ethics Committee for experiments on animals. Two lines of 1-day old Hubbard (Hubbard Co., Poland) male chickens, namely the Flex and F15 with dwarf genes, were used in this study. The purpose of using two lines of chickens was to check the effect of the supplementation on two genetically different animals to have a wider insight of Se activity. The average body weight of the chicks varied from 42 to $45 \mathrm{~g}$. Up to the $14^{\text {th }}$ day of life all birds received a starter diet in mashed form and had free access to drinking water (Table 1). Later, the chickens ( $n=144,72$ per one line) were split into three experimental groups containing: (i) 24 birds in the control group (C) fed with standard grower mixture containing 20\% crude protein and $13 \mathrm{MJ}$ metabolisable energy per kg; (ii) 24 birds in organic selenium (OSe) fed with a diet enriched with 0.5 $\mathrm{mg} \mathrm{Se} / \mathrm{kg}$ from selenised yeast Yarrowia lipolytica A6 (yeasts contained $4.98 \mathrm{mg} \mathrm{Se} / \mathrm{kg}$ were prepared by selenization procedure [11] at the Department of Biotechnology and Food Microbiology, Wroclaw University of Environmental and Life Sciences, Wroclaw, Poland; and (iii) 24 birds in the inorganic selenium group (IOSe) fed with a diet containing $0.5 \mathrm{mg} \mathrm{Se} / \mathrm{kg}$ from sodium selenite $\left(\mathrm{Na}_{2} \mathrm{SeO}_{3}\right.$, Sigma, Poznan, Poland). In each group birds were divided into six four-bird cages. All birds were fed and watered ad libitum. The vitamin/mineral premix added to the feeding mixtures was free of selenium and other supplements. To ensure the required hygienic standard for broiler chickens, coccidiostatic Diclazuril was used. The environmental conditions were constant during the study: ambient temperature $21^{\circ} \mathrm{C}$, humidity $68-70 \%$ and the lighting program comprised of $16 \mathrm{~h}$ light and $8 \mathrm{~h}$ darkness. The flocks from which the experimental chicks originated were subjected to a standard antiviral vaccination regimen. Experimental chicks were previously checked for the presence of Salmonella, Mycoplasma as well as their general health status has been monitored to make sure the chickens are clinically healthy. Coccidiostatic was applied on daily basis, as it is the usual practice. At day 35 of the study, randomly selected chickens from each cage of the experimental group and line were selected (44 in total), individually weighed, then slaughtered by spine dislocation. Blood was collected directly from the cervical vein. Bursa of Fabricius, thymus and spleen, were harvested and either immediately frozen 
in liquid nitrogen, or for the samples for histological analysis, directly fixed in $4 \%(\mathrm{v} / \mathrm{v})$ buffered formaldehyde solution ( $\mathrm{pH} 7.4)$.

Table 1. Composition of experimental diets

\begin{tabular}{|c|c|c|c|c|}
\hline \multirow{2}{*}{ Item } & \multirow{2}{*}{ Starter } & \multicolumn{3}{|c|}{ Treatments - grower diets } \\
\hline & & Control & OSe & IOSe \\
\hline Maize, $\mathrm{g} / \mathrm{kg}$ & 200 & 200 & 200 & 200 \\
\hline Wheat, $\mathrm{g} / \mathrm{kg}$ & 390 & 426 & 425 & 426 \\
\hline Rapeseed oil, g/kg & 40 & 55 & 55 & 55 \\
\hline Soya bean meal, $\mathrm{g} / \mathrm{kg}$ & 328 & 277 & 277 & 277 \\
\hline Premix dka-s $\mathrm{g} / \mathrm{kg} *$ & 40 & 40 & 40 & 40 \\
\hline DL-methionine (98\%), g/kg & 2.32 & 2.28 & 2.28 & 2.28 \\
\hline Selenium yeast, $\mathrm{g} / \mathrm{kg}$ & & & 1.13 & \\
\hline Sodium selenite, $\mathrm{mg} \mathrm{Se} / \mathrm{kg}$ & & & & 0.036 \\
\hline Metabolizable energy, MJ/kg & 12.5 & 13.0 & 13.0 & 13.0 \\
\hline Crude protein, $\mathrm{g} / \mathrm{kg}$ & 222 & 202 & 203 & 204 \\
\hline Crude fibre, $\mathrm{g} / \mathrm{kg}$ & 27.8 & 27.1 & 27.1 & 27.6 \\
\hline Crude fat, $\mathrm{g} / \mathrm{kg}$ & 58.5 & 73.1 & 74.6 & 72.8 \\
\hline Crude ash, $\mathrm{g} / \mathrm{kg}$ & 68.2 & 64.8 & 65.2 & 66.8 \\
\hline NPN & 521 & 528 & 526 & 513 \\
\hline Lysine, $\mathrm{g} / \mathrm{kg}$ & 13.6 & 12.1 & 12.4 & 12.4 \\
\hline Methionine, $\mathrm{g} / \mathrm{kg}$ & 5.44 & 5.21 & 5.11 & 5.27 \\
\hline Calcium, $\mathrm{g} / \mathrm{kg}$ & 10.5 & 10.2 & 10.2 & 10.1 \\
\hline Phosphorus $_{\text {avallble, }} \mathrm{g} / \mathrm{kg}$ & 5.86 & 5.75 & 5.74 & 5.85 \\
\hline Sodium, $\mathrm{g} / \mathrm{kg}$ & 2.15 & 2.19 & 2.16 & 2.17 \\
\hline Se, $\mathrm{mg} / \mathrm{kg}$ & 0.150 & 0.140 & 0.510 & 0.500 \\
\hline
\end{tabular}

*1 kg of premix provided: vitamin A (retinyl acetate) 700,000 IU; vitamin $\mathrm{D}_{3}$ (cholecalciferol) 100,000 IU; vitamin. E (DL- $\alpha$-tocopheryl acetate) $1,000 \mathrm{mg}$; vitamin $\mathrm{K}$ (hetrazeen vit. $\mathrm{K}_{3}$ free from menadione) $150 \mathrm{mg}$; vitamin $\mathrm{B}_{1}$ (thiamine mononitrate) $70 \mathrm{mg}$; vitamin $\mathrm{B}_{2}$ (riboflavin) $400 \mathrm{mg}$; vitamin $\mathrm{B}_{6}$ (pyridoxine $\mathrm{HCl}$ ) $30 \mathrm{mg}$; vitamin $\mathrm{B}_{12}$ (cyanocobalamin) $1 \mathrm{mg}$; biotin (D-biotin) $5 \mathrm{mg}$; choline (choline chloride) 20,000 mg; folic acid $20 \mathrm{mg}$; nicotic acid 1,000 mg; Fe (as $\mathrm{FeSO}_{4} \times \mathrm{H}_{2} \mathrm{O}$ ) 1,100 mg; $\mathrm{Mn}$ (as $\mathrm{MnO}_{2}$ ) 5,000 mg; Cu (as $\mathrm{CuSO}_{4}$ × $5 \mathrm{H}_{2} \mathrm{O}$ ) $200 \mathrm{mg} ; \mathrm{Zn}$ (as $\mathrm{ZnO}$ ) 3,000 mg; I (as $\left.\mathrm{Ca}\left(\mathrm{IO}_{3}\right)_{2}\right) 20 \mathrm{mg}$; $\mathrm{Co}\left(\right.$ as $\left.\mathrm{CoCO}_{3}\right) 30 \mathrm{mg}$.

\section{Immunological analysis}

All harvested immune system organs were weighed on a laboratory scale $( \pm 0.01 \mathrm{~g})$, relative weights were calculated, and expressed as a percentage of organ weight to body weight [3]. The relative weight ratios of the bursa of Fabricius/thymus, spleen/ thymus and spleen/bursa of Fabricius were also calculated. 


\section{Histological examination and morphometry}

Samples of the bursa of Fabricius, thymus and spleen were routinely processed in paraffin. Sections ( $5 \mu \mathrm{m}$ thick) of each sample were stained H\&E with Delafield haematoxylin (Roth GmbH, Karlsruhe, Germany) and eosin (Poch S.A., Gliwice, Poland). The slices were examined and photographed under a light microscope (Nikon Eclipse 80i; Nikon, Melville, NY, USA) with a video camera. Morphometric analysis was conducted using the obtained photographs (original magnification 100×) and NISElements AR 2.30 (Nikon) imaging software. In thymus, the cortex/medulla diameter ratio was measured in 3 lobules from each sample. In the bursa of Fabricius, the ratio of the cortex/medulla area was measured in transverse sections of 3 individual follicles from each sample. In the spleen, the areas of the germinal centres were added together and expressed as a percentage of the total field of view.

\section{Statistical analysis}

All data were evaluated statistically by one or two factorial ANOVA using Statistica 13.1 software (StatSoft Polska Sp. z o. o., Cracow, Poland). Data are presented as average values and accompanied by standard deviation (SD). The significance of differences was assessed using either a Tukey or Kruskal Wallis ANOVA test, according to the normality of data distribution. A value of $\mathrm{p}<0.05$ was considered significant.

\section{RESULTS}

Control Flex groups were slightly $(p>0.05)$ heavier than control F15 groups. In the experimental groups, the final body weights of chickens fed with organic and inorganic selenium were significantly higher in the Flex group compared to F15 group.

To avoid the influence of differences in bird body weight, the weights of the harvested immune system organs of both Flex and F15 groups are presented as relative organ weights in Table 2. No significant differences were observed in the relative weights of the bursa of Fabricius. No significant differences in relative weights of the thymus were found between the experimental groups, although they were markedly higher in F15 than in Flex chickens, except the birds treated with inorganic selenium. No significant differences in average relative spleen weights were found between the chicken groups, although some differences were observed between the chicken lines. The relative spleen weight of the chickens in the F15 control group was the lowest while in the Flex control was higher than in both selenium supplemented groups (Flex OSe and Flex IOSe) (Table 2).

No significant differences between relative weights of the spleen to the bursa of Fabricius were found in the studied chicken groups (Table 2). The spleen to thymus ratio was higher in the Flex line chickens than the F15 line (Table 2), but no significant differences in spleen/thymus ratios were found within the respective chicken lines as a result of feed supplementation. The lowest relative weight ratio of the bursa of 
Fabricius to the thymus was found in F15 OSe chickens, with the highest $(p<0.05)$ in the Flex OSe group. No significant differences in this parameter were found between the chickens in the same line.

High concentrations of selenium (both organic and ionic forms) as well as methionine added to the feed did not affect the relative weight of any harvested immune organs.

Serum IgG concentrations were not significantly different between the control and experimental groups within the chicken lines (Table 2).

Table 2. Body weight (mean $\pm \mathrm{SD}$ ), relative weight of bursa of Fabricius, thymus and spleen and relative weight ratios of immune organs of Flex and F15 with dwarf gene chickens; Flex Hubbard Flex, F15 - Hubbard F15 line chickens; C - control group; OSe - organic selenium fed group; IOSe - inorganic selenium fed group; a-d - common letter indicate significant difference between groups at $\mathrm{p}<0.05$

\begin{tabular}{|c|c|c|c|c|c|c|c|}
\hline \multirow[b]{2}{*}{ Line } & \multirow[b]{2}{*}{$\begin{array}{c}\text { Body } \\
\text { weight } \\
{[\mathrm{kg}]}\end{array}$} & \multicolumn{3}{|c|}{ The relative weight [\%] } & \multicolumn{3}{|c|}{ Relative weight ratio } \\
\hline & & $\begin{array}{l}\text { bursa of } \\
\text { Fabricius }\end{array}$ & thymus & spleen & $\begin{array}{l}\text { spleen to } \\
\text { bursa of } \\
\text { Fabricius }\end{array}$ & $\begin{array}{l}\text { spleen to } \\
\text { thymus }\end{array}$ & $\begin{array}{l}\text { bursa of } \\
\text { Fabricius } \\
\text { to thymus }\end{array}$ \\
\hline F15 C & $\begin{array}{c}1.653 \\
\pm 0.161\end{array}$ & $\begin{array}{c}0.180 \\
\pm 0.043\end{array}$ & $\begin{array}{c}0.506 \\
\pm 0.067\end{array}$ & $\begin{array}{c}0.090 \\
\pm 0.027\end{array}$ & $\begin{array}{c}0.569 \\
\pm 0.256\end{array}$ & $\begin{array}{r}0.180^{\mathrm{a}} \\
\pm 0.059\end{array}$ & $\begin{array}{c}0.360 \\
\pm 0.064\end{array}$ \\
\hline F15 OSe & $\begin{array}{l}1.606^{a, c} \\
\pm 0.106\end{array}$ & $\begin{array}{c}0.148 \\
\pm 0.044\end{array}$ & $\begin{array}{c}0.496 \\
\pm 0.116\end{array}$ & $\begin{array}{c}0.103 \\
\pm 0.022\end{array}$ & $\begin{array}{c}0.770 \\
\pm 0.326\end{array}$ & $\begin{array}{c}0.220 \\
\pm 0.075\end{array}$ & $\begin{array}{c}0.325^{a} \\
\pm 0.160\end{array}$ \\
\hline F15 IOSe & $\begin{array}{l}1.556^{\mathrm{b}, \mathrm{d}} \\
\pm 0.246\end{array}$ & $\begin{array}{c}0.185 \\
\pm 0.050\end{array}$ & $\begin{array}{c}0.449 \\
\pm 0.165\end{array}$ & $\begin{array}{c}0.107 \\
\pm 0.020\end{array}$ & $\begin{array}{c}0.596 \\
\pm 0.086\end{array}$ & $\begin{array}{c}0.274 \\
\pm 0.112\end{array}$ & $\begin{array}{c}0.454 \\
\pm 0.140\end{array}$ \\
\hline Flex C & $\begin{array}{c}1.841 \\
\pm 0.156\end{array}$ & $\begin{array}{c}0.183 \\
\pm 0.036\end{array}$ & $\begin{array}{c}0.378 \\
\pm 0.101\end{array}$ & $\begin{array}{c}0.131 \\
\pm 0.045\end{array}$ & $\begin{array}{c}0.755 \\
\pm 0.326\end{array}$ & $\begin{array}{c}0.371^{\mathrm{a}} \\
\pm 0.199\end{array}$ & $\begin{array}{c}0.515 \\
\pm 0.170\end{array}$ \\
\hline Flex OSe & $\begin{array}{l}1.903^{\mathrm{a}, \mathrm{b}} \\
\pm 0.156\end{array}$ & $\begin{array}{c}0.195 \\
\pm 0.060\end{array}$ & $\begin{array}{c}0.360 \\
\pm 0.138\end{array}$ & $\begin{array}{c}0.116 \\
\pm 0.034\end{array}$ & $\begin{array}{c}0.665 \\
\pm 0.376\end{array}$ & $\begin{array}{c}0.369 \\
\pm 0.217\end{array}$ & $\begin{array}{l}0.585^{\mathrm{a}} \\
\pm 0.207\end{array}$ \\
\hline Flex IOSe & $\begin{array}{l}1.891^{\mathrm{c}, \mathrm{d}} \\
\pm 0.169 \\
\end{array}$ & $\begin{array}{c}0.154 \\
\pm 0.038 \\
\end{array}$ & $\begin{array}{c}0.424 \\
\pm 0.145 \\
\end{array}$ & $\begin{array}{c}0.125 \\
\pm 0.054 \\
\end{array}$ & $\begin{array}{c}0.845 \\
\pm 0.385 \\
\end{array}$ & $\begin{array}{c}0.348 \\
\pm 0.220 \\
\end{array}$ & $\begin{array}{c}0.395 \\
\pm 0.129 \\
\end{array}$ \\
\hline
\end{tabular}

\section{Histopathological findings}

Selenium supplementation affected the morphology of immune system organs in the examined chickens (Figure 1 and 2). The bursa of Fabricius in both the supplemented groups contained mucosal folds filled with follicles. The epithelial cortico-medullary border in the follicles was corrugated with several folds. Organic selenium supplementation in the F15 line caused dramatic changes - the number of lymphocytes in the medulla decreased, uncovering the stromal cell meshwork, and the cortex was thinned in some follicles. Inorganic selenium supplementation in the F15 line also dramatically depopulated BF of lymphocytes uncovering clusters of stromal cells in the medulla.

The thymus lobes of the chickens in both control and experimental groups were divided by septa of connective tissue into incompletely separated lobules. In each lobule, strands of connective tissue derived from interlobular septa penetrated the 
peripheral cortex and reached the heavily corrugated cortico-medullary border. The lobules in the control groups were elongated. Several small thymic (Hassall's) corpuscles were observed in the medulla and many capillaries were heavily filled with blood. Numerous heterophils in the medulla were observed in the F15 line. Organic selenium partially depleted the cortex of the lymphoid cells in the F15 group, so that the stromal cell meshwork resembled that of the medulla. Congestion in the medulla was observed in single lobules in both F15 and Flex lines. Inorganic selenium added to the feed for chickens in the Flex line caused severe haemorrhages which were observed in almost the entire medulla in some lobules. Congestion and small haemorrhages were observed in the cortex as well.
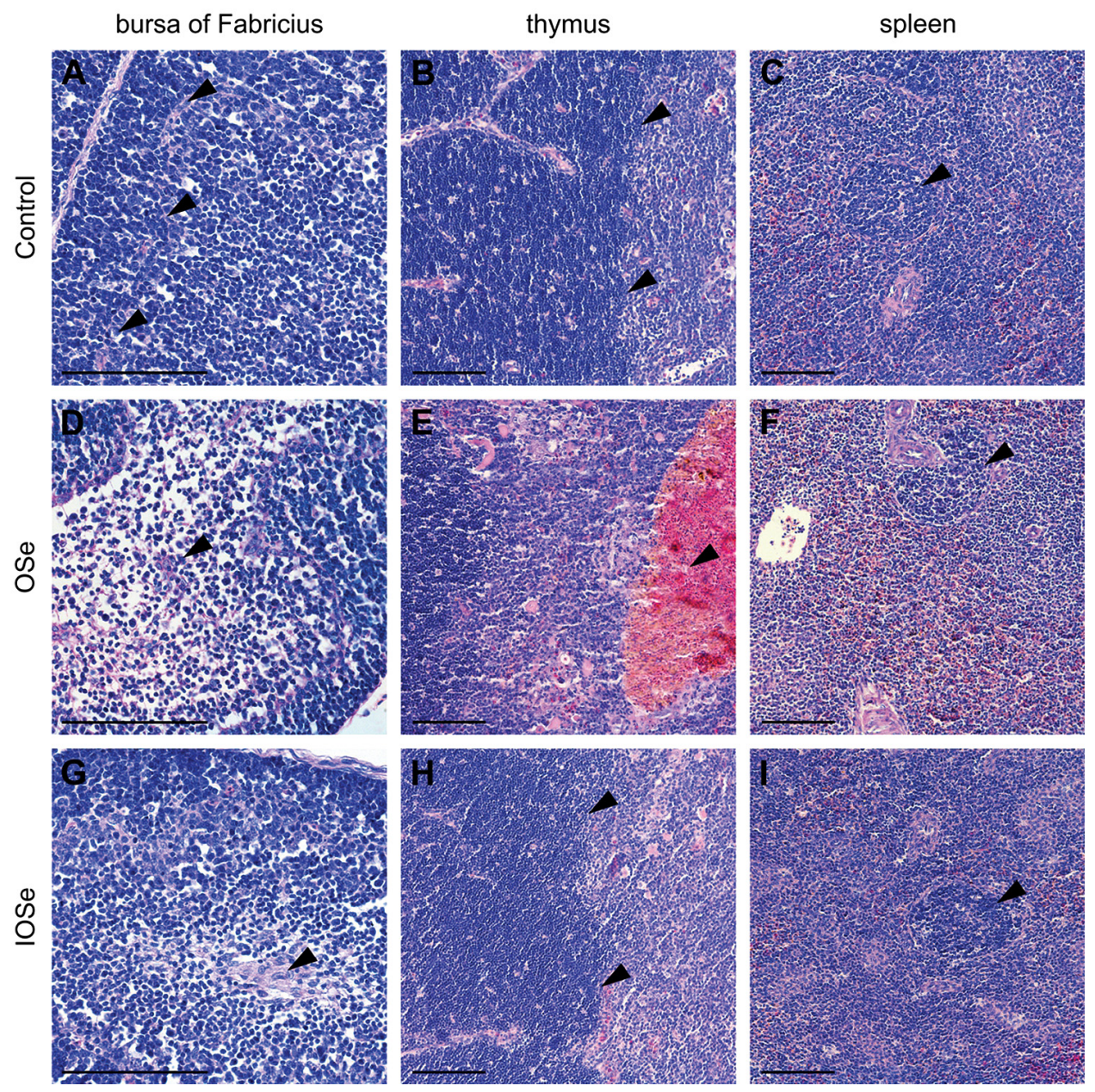

Figure 1. Histopathological changes in bursa of Fabricius $(400 \times)$, thymus $(200 \times)$ and spleen $(200 \times)$ in control group of F15 chicken and after feeding with high concentration of organic selenium (OSe) and inorganic selenium (IOSe). Scale bar - $100 \mu \mathrm{m}$. A - cortico-medullary border, $\mathbf{D}, \mathbf{G}$ - depopulation of lymphocytes from the medulla with uncovering of reticular endothelial cells, $\mathbf{B}$ - cortico-medullary border, $\mathbf{E}$ - large haemorrhage in the medulla, $\mathbf{H}$ cortico-medullary border, structure of the organ similar to control group, $\mathbf{C}$-germinal centre, F, I - germinal centres similar to control group. 
The spleens of the broilers in all groups were sometimes divided by a barely visible border between the red and white pulp. The latter consisted of lymphatic nodules and periarteriolar lymphatic sheaths (PALS) with a small number of clearly demarcated germinal centres (GCs). The number of GCs in all Se-supplemented groups was slightly higher than that observed in the control group, but the difference was not significant.
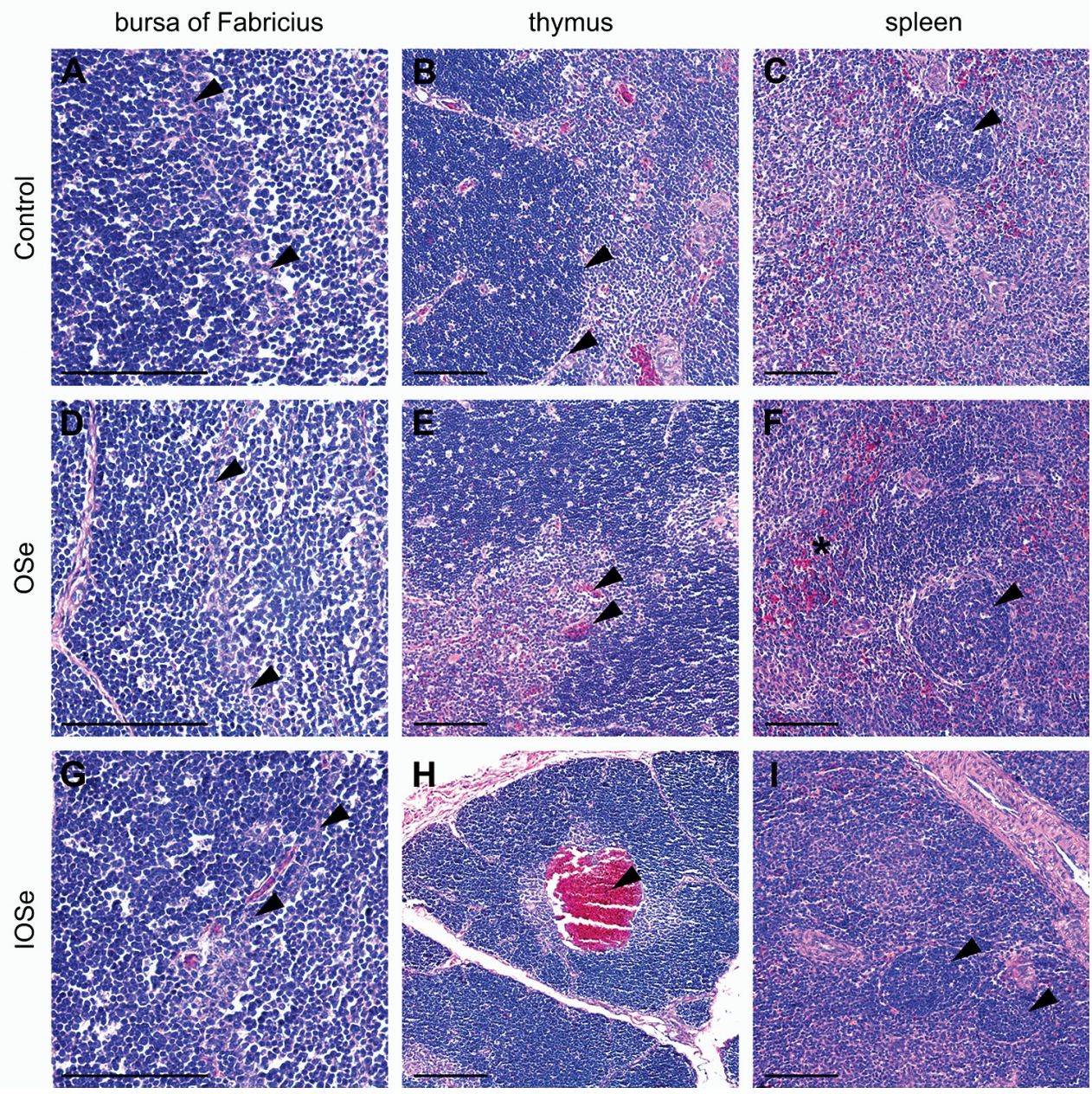

Figure 2. Histopathological changes in bursa of Fabricius (400x), thymus $(200 \times)$ and spleen $(200 \times)$ in control group of Flex chicken and after feeding with high concentration of organic selenium (OSe) and inorganic selenium (IOSe). Scale bar - $100 \mu \mathrm{m}$. A - cortico-medullary border, $\mathbf{D}, \mathbf{G}$ - cortico-medullary border, structure of the organ similar to control group, $\mathbf{B}-$ cortico-medullary border, $\mathbf{E}$ - congestion of capillaries in the medulla, $\mathbf{H}$ - large haemorrhages in the medulla, $\mathbf{C}$ - germinal centre, $\mathbf{F}$ - germinal centre number similar to control group, increased number of heterophils (asterisk), I - slightly increased germinal centre number. 


\section{Morphometrics}

Statistical analysis of the bursal follicles showed that the cortex/medulla ratios were similar in all groups studied. Interestingly, the values of the ratios oscillated around the value of 1 . Supplementation of the diet influenced the cortex/medulla ratio in the thymus, that the diameter ratios significantly decreased in the organic seleniumsupplemented group in comparison to control group in the F15 line (Table 3). The germinal centre area showed a slight tendency (but statistically insignificant $\mathrm{p}>0.05$ ) to increase in both selenium-supplemented groups in Flex line.

Table 3. The morphometric analysis of immune organs (mean \pm SD). Flex - Hubbard Flex, F15 - Hubbard F15 line; C - control group; OSe - organic selenium fed group; IOSe inorganic selenium fed group. ${ }^{*} \mathrm{p}<0.05$ (in comparison to control).

\begin{tabular}{|c|c|c|c|c|c|c|}
\hline & F15 C & $\begin{array}{l}\text { F15 } \\
\text { OSe }\end{array}$ & $\begin{array}{c}\text { F15 } \\
\text { IOSe }\end{array}$ & Flex C & $\begin{array}{l}\text { Flex } \\
\text { OSe }\end{array}$ & $\begin{array}{l}\text { Flex } \\
\text { IOSe }\end{array}$ \\
\hline $\begin{array}{l}\text { The ratio of diameter of the } \\
\text { thymus cortex to the medulla }\end{array}$ & $\begin{array}{c}2.22 \\
\pm 0.60\end{array}$ & $\begin{array}{l}1.15^{*} \\
\pm 0.40\end{array}$ & $\begin{array}{c}1.28 \\
\pm 0.27\end{array}$ & $\begin{array}{c}1.27 \\
\pm 0.46\end{array}$ & $\begin{array}{c}1.19 \\
\pm 0.42\end{array}$ & $\begin{array}{c}1.57 \\
\pm 0.41\end{array}$ \\
\hline $\begin{array}{l}\text { The cortex to the medulla ratio in } \\
\text { follicles of bursa of Fabricius }\end{array}$ & $\begin{array}{c}0.98 \\
\pm 0.31\end{array}$ & $\begin{array}{l}0.95 \\
\pm 0.20\end{array}$ & $\begin{array}{c}1.00 \\
\pm 0.34\end{array}$ & $\begin{array}{c}1.02 \\
\pm 0.19\end{array}$ & $\begin{array}{c}0.95 \\
\pm 0.21\end{array}$ & $\begin{array}{l}1.04 \\
\pm 029\end{array}$ \\
\hline Germinal center area in the spleen & $\begin{array}{c}0.46 \\
\pm 0.43\end{array}$ & $\begin{array}{c}0.53 \\
\pm 0.48\end{array}$ & $\begin{array}{c}0.54 \\
\pm 0.37\end{array}$ & $\begin{array}{c}0.34 \\
\pm 0.37\end{array}$ & $\begin{array}{c}0.54 \\
\pm 0.43\end{array}$ & $\begin{array}{l}0.49 \\
\pm 037\end{array}$ \\
\hline
\end{tabular}

\section{DISCUSSION}

Selenium is an essential nutrient in poultry nutrition and plays a crucial role in the antioxidative status of the body by participating within active centres of glutathione peroxidase. Organic and inorganic Se injected in ovo at doses up to $40 \mu \mathrm{g} \mathrm{Se} / \mathrm{egg}$ affected embryo viability only slightly, yet the addition of $0.3 \mathrm{mg} / \mathrm{kg}$ of feed for laying hens improved tissue Se status in chicks at hatching. The addition of $20 \mathrm{mg} / \mathrm{kg}$ l-selenomethionine increased the final body weight and antibody-mediated immune response in ducks, however $60 \mathrm{mg} / \mathrm{kg}$ Se in the diet rapidly decreased the body weight and reduced the immune response [7]. For smaller birds such as chickens, a diet enriched with $1 \mathrm{mg} / \mathrm{kg}$ of selenium improved the antibody immune response during experimental salmonellosis with or without aflatoxicosis [12]. Moreover, Chen et al. [8] reported that diets supplemented with sodium selenite $(0.2-0.6 \mathrm{mg} / \mathrm{kg})$ improved cellular immune function impaired by aflatoxin B1 by increasing the relative weight of the spleen, percentages of splenic T cell subsets, and alleviating histopathological spleen damage. In our study, in both selenium supplemented groups the germinal centres area in the spleen slightly increased. It suggests the stimulatory effect of selenium additive on B cells. Similarly, to the results of Cai et al. [13], dietary Se did not influence the relative weight of the spleen, bursa of Fabricius or thymus. This was likely due to the low selenium level in the diet $(0.5 \mathrm{mg} / \mathrm{kg})$ or relatively short time of supplementation. Studies on Japanese quail revealed that Se added to the diet increased the relative weight of bursa of Fabricius and thymus in 6-week-old birds 
[6]. This suggests that an increased Se concentration helps to protect proliferating immature bursal B cells and thymic T-lymphocytes from oxidative stress [14].

In our study the selenium supplementation in none of the preparation did affect the relative weights of the bursa of Fabricius, spleen or thymus. This is in agreement with the results of Niu et al. [3], which showed that none of the lymphoid organ relative weights were significantly affected by Se supplementation at $0.2-1.2 \mathrm{mg} / \mathrm{kg}$ in the diet.

The results of the present study show that organic and inorganic selenium compounds decreased the number of lymphocytes in the medulla of bursa and cause severe thymic lesions, but had no impact on the cortex to medulla ratios in bursal follicles. The effect of selenium supplementation on cortex/medulla ratios in the thymus is not clear due to significant differences between the broiler lines. Additionally, in Flex line the spleen looks slightly stimulated.

The depression of the thymic lobule at $0.1 \mathrm{mg}$ and $0.5 \mathrm{mg}$ selenium (sodium selenite) supplementation was previously revealed by histological observation [15], but our measurements did not confirm these results. Peng et al. [16] reported that supplementation of $1 \mathrm{mg}$ of Se (sodium selenite) in $1 \mathrm{~kg}$ of feed did not influence the percentage of apoptotic splenocytes. On the contrary, it significantly decreased the relative weight of bursa and the number of lymphocytes in lymphoid nodules [17], but by pathological observation no obvious changes in the BF were observed. It was also reported that histologically, the population of lymphocytes decreased in the medulla of bursal follicles and splenic masses in inorganic selenium-supplemented broilers (0.1 $\mathrm{mg}$ and $0.5 \mathrm{mg}$ ) as compared to the control [15]. We also observed lymphocyte depopulation in bursal follicles in the two selenium-supplemented groups, but the GC area in the spleen was slightly higher than in the control group.

\section{CONCLUSIONS}

Feed additives used in the study did not affect the relative weight of immune organs. In the F15 group both the organic and inorganic selenium supplementation (each at $0.5 \mathrm{mg} / \mathrm{kg}$ ) resulted in depopulation of bursal medulla from lymphocytes. Moreover, in the F15 group organic selenium resulted in thinning of the thymic cortex and partial depletion of the lymphoid cells. In Flex chickens no significant differences in histological structure and morphometric values of lymphoid organs between chickens fed organic and inorganic selenium were found. Selenium obviously influences the histological structure of thymus, Bursa Fabricii and spleen in healthy broilers but further research is needed to find out what the relationship and the implications for immune status are.

\section{Acknowledgements}

This work was supported by the Polish Ministry of Science and Higher Education - project no N N312 253938. Publication supported by the Wroclaw Centre of 
Biotechnology, programme the Leading National Research Centre (KNOW) for 20142018.

\section{Authors' contributions}

MK design the whole study, performed the experiments, helped to draft the manuscript. JPM performed the histological examination, morphometry and statistical analysis, analysed the data and drafted the manuscript. TS performed immunological analysis and interpretation of data, helped to draft the manuscript. WK participated in the design of the study and helped to draft the manuscript. All authors have approved the final version of the manuscript.

\section{Declaration of conflicting interests}

The author(s) declared no potential conflicts of interest with respect to the research, authorship, and/or publication of this article.

\section{REFERENCES}

1. Kidd MT: Nutritional modulation of immune function in broilers. Poult Sci 2004, 83:650657.

2. Payne RL, Southern LL: Comparison of inorganic and organic selenium sources for broilers. Poult Sci 2005, 84:898-902.

3. Niu Z, Liu F, Yan Q, Li L: Effects of different levels of selenium on growth performance and immunocompetence of broilers under heat stress. Arch Anim Nutr 2009, 63:56-65.

4. Habibian M, Ghazi S, Mehdi Moeini M, Abdolmohammadi A: Effects of dietary selenium and vitamin $\mathrm{E}$ on immune response and biological blood parameters of broilers reared under thermoneutral or heat stress conditions. Int J Biometeorol 2014, 58:741-752.

5. Todorović M, Jovanović M, Jokić Ž, Hristov S, Davidović V: Alterations in liver and kidneys of chickens fed with high levels of sodium selenite or selenized yeast Acta VeterinariaBeograd, 2004, 54(2-3):191-200.

6. Biswas A, Mohan J, Sastry KVH: Effect of higher levels of dietary selenium on production performance and immune responses in growing Japanese quail. Br. Poult Sci 2006, 47:511515.

7. Franson JC, Hoffman DJ, Wells-Berlin A, Perry MC, Shearn-Bochsler V, Finley DL, Flint PL, Hollmen T: Effects of dietary selenium on tissue concentrations, pathology, oxidative stress, and immune function in common eiders (Somateria mollissima). J Toxicol Environ Health Part A 2007, 70:861-874.

8. Chen K, Peng X, Fang J, Cui H, Zuo Z, Deng J, Chen Z, Geng Y, Lai W, Tang L, Yang Q: Effects of dietary selenium on histopathological changes and $T$ cells of spleen in broilers exposed to aflatoxin B1. Int J Environ Res Pub Health 2014, 11:1904-1913.

9. Ryu YC, Rhee MS, Lee KM, Kim BC: Effects of different levels of dietary supplemental selenium on performance, lipid oxidation, and color stability of broiler chicks. Poult Sci 2005, 84:809-815. 
10. Bjelica J, Jovanović I, Ilić V, Valčić O, Kirovski D, Gvozdić D, Milanović S: Effects of selenium and thyroid hormone deficiency on peritoneal macrophages adhesion and occurrence of natural IgM antibodies in juvenile rats. Acta Veterinaria-Beograd 2017, 67(3):340-355.

11. Juszczyk P, Smolczyk A, Gil Z, Rymowicz W: Production of the Yarrowia lipolytica fodder yest enriched in selenoaminoacids and B12 vitamin. Inż Ap Chem 2015, 54:165-166.

12. Hegazy SM, Adachi Y: Comparison of the effects of dietary selenium, zinc, and selenium and zinc supplementation on growth and immune response between chick groups that were inoculated with Salmonella and aflatoxin or Salmonella. Poult Sci 2000, 79:331-335.

13. Cai SJ, Wu CX, Gong LM, Song T, Wu H, Zhang LY: Effects of nano-selenium on performance, meat quality, immune function, oxidation resistance, and tissue selenium content in broilers. Poult Sci 2012, 91:2532-2539.

14. Swain BK, Johri TS, Majumdar S: Effect of supplementation of vitamin E, selenium and their different combinations on the performance and immune response of broilers. $\mathrm{Br}$ Poult Sci 2000, 41:287-292.

15. Khan MZ, Akter SH, Islam MN, Karim MR, Islam MR, Kon Y: The effect of selenium and vitamin $\mathrm{E}$ on the lymphocytes and immunoglobulin-containing plasma cells in the lymphoid organ and mucosa-associated lymphatic tissues of broiler chickens. Anatom Histol Embryol 2008, 37:52-9.

16. Peng X, Cui H, He Y, Cui W, Fang J, Zuo Z, Deng J, Pan K, Zhou Y, Lai W: Excess dietary sodium selenite alters apoptotic population and oxidative stress markers of spleens in broilers. Biol Tr Elem Res 2012, 145:47-51.

17. Peng X, Cui Y, Cui W, Deng J, Cui H: The decrease of relative weight, lesions, and apoptosis of bursa of Fabricius induced by excess dietary selenium in chickens. Biol Tr Elem Res 2009, 131:33-42.

\title{
UTICAJ SELENA NA MORFOLOGIJU ORGANA IMUNSKOG SISTEMA KOD ZDRAVIH BROJLERA
}

\author{
KORZENIOWSKA Malgorzata, MADEJ Jan P., STEFANIAK Tadeusz, \\ KOPEC Wieslaw
}

Cilj studije je bio da se ustanovi uticaj suplementacije organskim i neorganskim selenom hrane za brojlere na telesnu masu i građu timusa, Fabricijeve burze i slezine. İspitivana su tri sistema ishrane kod Flex i F15 Hubbard pilića i to: (I) kontrolna grupa, (II) ishrana koja je podrazumevala dodavanje $0,5 \mathrm{mg}$ organskog selena/kg upotrebom seleniziranog kvasca, kao i (III) ishrana koja je podrazumevala suplementaciju 0,5 mg neorganskog selena/kg (natrijum selenit). Rezultati su pokazali da ishrana sa aditivima nije imala nikakav uticaj na relativne mase i težinu organa imunskog sistema tj. Fabricijeve burze, timusa i slezine. Suplementacija organskim selenom kod F15 brojlera, je za posledicu imala istanjenost korteksa timusa i parcijalnu depleciju limfocita. 
Uz ovo, suplementacija kako organskim tako i neorganskim selenom, kao rezultat je imala limfocitnu depopulaciju medule burze u F15 grupi. Nasuprot ovome, kod Flex pilića, nisu uočene razlike u histološkim strukturama i morfometrijskim parametrima limfoidnih organa između grupa pilića hranjenih sa organskim i neorganskim selenom. 